D.R. Bevan MB MrCP FFarCs, F. Donati PH D MD, H. Gyasi MB FFARCS, A. Williams MB FFarCs

\title{
Vecuronium in renal failure
}

Neuromuscular blockade during surgery was provided with vecuroniam in 24 adult patients in end-stage renal failure and in 21 normal patients who served as comrols Dose response curves were constructed which showed that the effective doses required to produce 50,90 and 95 per cent neuromuscular blockude in patients with renal failure were $27.5,43$ and $49 \mu \mathrm{g} \cdot \mathrm{kg}^{-1}$ respectively. These were not significantly different from the doses of 31,49 and $57 \mu \mathrm{g} \cdot \mathrm{kg}^{-1}$ in the normal patients. Repeated small doses of $0.01 \mathrm{mg} \mathrm{kg}^{-1}$ hed a significantly longer duration of artion and were associated wilh some cumulation in the renal failure group. Recovery from the block occured rapidly after neostigmine, was no different in renal failure and was not associated with recurarization. It is concluded that, when given to subjects in renal failure, vecuronium offers advanrages over established agents such as shorter duration of action and easy reversibility.

Key words

NEUROMUSCULAR RELAXANTS: vecuronium; RENAL FAILURE: anaesthesia.

All non-depolarizing neuromuscular blocking drugs are ionized quaternary ammonium compounds and, because they are water soluble, are excreted in the urine. Consequently, their duration of action is prolonged in renal failure unless they are metabolized rapidly. The degree to which renal impairment influences their duration of action depends on the presence of alternative routes of excretion. Vecuronium is a monoquaternary analogue of pancuronium which has been released recently for clinical use in the United States. Although the kidney is an important site of clearance, the liver is the major

From the Departments of Anaesthesia, Royal Victoria Hospital \& McGill University, Montreal, Quebec.

Address correspondence to: Dr. D.R. Bevan,

Department of Anaesthesia, Royal Victoria Hospital, 687 Pine Avenue West, Montreal, Que., H3A 1A1. route of excretion in animals. ${ }^{1}$ In addition, vecuronium undergoes spontaneous deacetylation to hy droxy metabolites ${ }^{2}$ which have minimal neuromuscular blocking effects. ${ }^{3}$ These alternative mechanisms probably explain why the duration of action of equipotent doses of vecuronium in normal subjects is only one-third that of pancuronium. ${ }^{4}$

Its action should be altered little by renal dysfunction althrough the available evidence is scanty. In rats, clamping of the renal arteries did not alter significantly the depth or duration of vecuronium blockade. ${ }^{5}$ In man, renal failure is associated with only small increases in the duration of neuromuscular block and recovery rate ${ }^{6}$ as a result of statisically insignificant alterations in the pharmacokinetic behaviour of vecuronium in renal failure.? However, these observations are based upon small patient populations and there is no information of the potency, cumulative tendency, or reversibility of vecuronium in renal failure in man.

The present study was designed to compare the potency, duration of action, cumulative tendency of repeated doses and the reversibility of vecuronium in patients with normal renal function and with those in end-stage renal failure

\section{Methods}

The protocol was approved by the hospital Ethics Committee. After informed consent had been obtained, 45 adult surgical patients were studied. Twenty-one of the patients had normal renal function, were ASA physical status class I-II, werc without known or suspected neuromuscular disease, and were not taking medication known to interfere with neuromuscular transmission. These patients constituted the control group. Twenty four patients were in end-stage renal failure undergaing a variety of surgical procedures; renal transplantation (7), dialysis access (13), transplant nephrectomy (2), parathyroidectomy (1) and laparotomy (1).

Patients in both groups received premedication with a narcotic and atropine intramuscularly approximately $60 \mathrm{~min}$ before surgery. Anaesthesia 
was induced with thiopentone, $3-5 \mathrm{mg} \mathrm{kg}^{-1}$, and maintained with nitrous oxide, $50-70$ per cent, in oxygen and supplemented with halothane $(0.5-1$ per cent inspired). The traclseas of all patients were intubated and the lungs ventilated to maintain an end-tidal $\mathrm{PCO}_{2}$ of $32-35 \mathrm{mmHg}$ (Hewlett Packard capnometer).

Neuromuscular transmission was measured, after induction of anaesthesia until the end of surgery, using train-of-four stimulation according to the method of Ali et al. ${ }^{8}$ The ulnar nerve was stimulated supramaximally at the elbow with subcutaneous ncedle electrodes. Four square wave impulses of $0.2 \mathrm{~ms}$ duration and $2 \mathrm{~Hz}$ frequency were administered every 12 seconds using a Grass $\$ 48$ stimulator and SIU5 isolation unit. The hand and forearm were immobilized in a splint. The force of contraction of the adductor pollicis muscle was measured with a Grass FT 10 force displacement transducer and the response recorded on a Grass Polygraph pen and ink recorder. The skin temperature over the thumb was monitored and maintained above $32^{\circ} \mathrm{C}$.

After stabilization of muscle twitch had been obtained, vccuronium was injceted as a single bolus of one of 11 doses between 10 and $60 \mu \mathrm{g} \cdot \mathrm{kg}^{-1}$. At least two patients received each dose which was chosen by random allocation. Twitch depression was measured after it had reached a stable level and these data points were used to construct a doseresponse curve using log-probit paper. ${ }^{9}$ Additional doses, $10-20 \mu \mathrm{g} \cdot \mathrm{kg}^{-1}$, of vecuronium were given to produce twitch depression of at least 95 per cent. Neuromuscular blockade was maintained during surgery with repeated boluses of $10 \mu \mathrm{g} \cdot \mathrm{kg}^{-1}$ given whenever the force of the first stimulus of the train returned to ten per cent of control. Towards the end of surgery the neuromuscular block was antagonized with atropine, $1.2 \mathrm{mg} \cdot 70 \mathrm{~kg}^{-1}$, and neostigmine, $2.5 \mathrm{mg} \cdot 70 \mathrm{~kg}^{-1}$. Monitoring of neuromuscu?ar transmission continued until the train of four ratio (T4/T1), defined as the force of contraction of

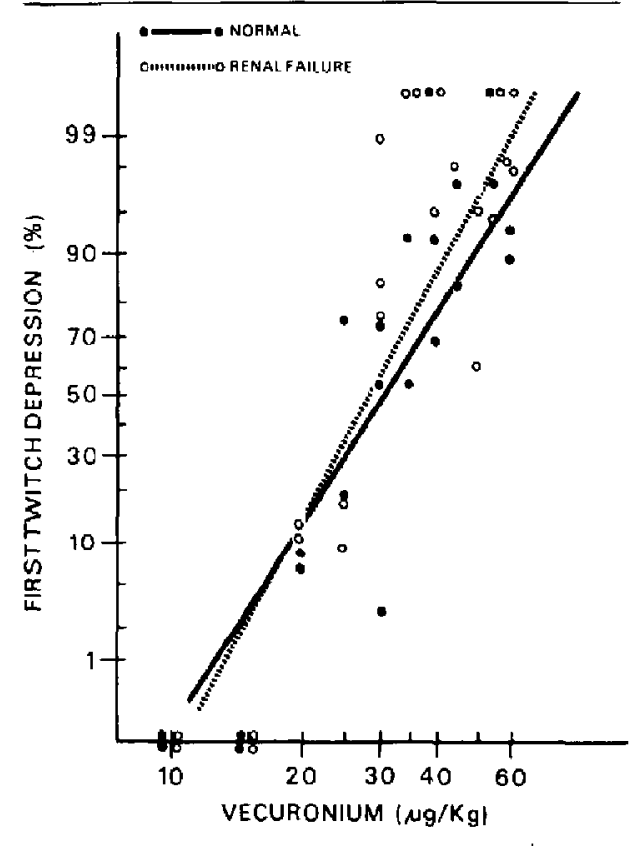

FIGURE 1 Single dose, vecuronim log-probit dose response curves in normal and renal failure patients. Data points for 0 ani: 100 per cent block were excluded from consiruction of regression lines.

the fourth twitch in each train divided by the force of contraction of the first, exceeded 0.7 . Then the patients were extubated and returned to the recovely room where neuromuscular activity was assessed by the usual clinical criteria which included adequacy of respiration, hand grip and head lift.

Regression lines for dose response curves were constructed by the method of least squares excluding points of 0 and 100 per cent block. The curves in the normal and renal failure patients were compared graphically as a $\log$-probit plot and analyzed for parallelism and potency. Mean values are presented with the standard error of the mean as the index

TABLE [ Demographic data

\begin{tabular}{|c|c|c|c|c|c|c|}
\hline & \multirow[b]{2}{*}{$n$} & \multicolumn{2}{|c|}{ Sext } & \multirow{2}{*}{$\begin{array}{l}\text { Age } \\
y r s\end{array}$} & \multirow{2}{*}{$\begin{array}{l}\text { Wr } \\
\mathrm{kg}\end{array}$} & \multirow{2}{*}{$\begin{array}{l}\text { Dirrafion } \\
\text { mirt }\end{array}$} \\
\hline & & $M$ & $: F$ & & & \\
\hline Normal & 21 & 13 & $: 8$ & $50.6 \pm 3.0$ & $67.1 \pm 2.1$ & $109.0 \pm 17.6$ \\
\hline Renal failure & 24 & 12 & $: 12$ & $45.1 \pm 3.2$ & $65.5 \pm 3.1$ & $89.3 \pm 14.9$ \\
\hline
\end{tabular}


TABLE II Laboratory data

\begin{tabular}{|c|c|c|c|c|c|c|c|c|}
\hline & $\begin{array}{l}H b \\
g \cdot d l^{-1}\end{array}$ & $\begin{array}{l}\text { Nal } \\
m m o l \cdot 1^{-1}\end{array}$ & $\begin{array}{l}K \\
m m a l \cdot l^{-1}\end{array}$ & $\begin{array}{l}\mathrm{Ca} \\
\mathrm{mmol} \cdot \mathrm{j}^{-}\end{array}$ & $\begin{array}{l}B L W \\
m g \cdot d l^{-\prime}\end{array}$ & $\begin{array}{l}\mathrm{Cr} \\
m g \cdot d l^{-1}\end{array}$ & $\begin{array}{l}\text { Albumen } \\
8 \cdot d l^{\prime}\end{array}$ & $\begin{array}{l}\text { Prolein } \\
g \cdot d l\end{array}$ \\
\hline Normal & $14.1=0.3$ & $141.0 \pm 0.6$ & $4.2 \pm 0.1$ & $9.4 \pm 0.1$ & $13.4 \pm 1.0$ & $0.96 \pm 0.04$ & $4.1 \pm 0.08$ & $6.9 \pm 0.1$ \\
\hline Renal failure & $8.9 \pm 0.4$ & $136.7 \pm 1.0$ & $4.7 \pm 0.2$ & $9.1 \pm 0.2$ & $83.4 \pm 7.2$ & $11.5 \pm 0.9$ & $3.7 \pm 0.1$ & $6.4 \pm 0.1$ \\
\hline $\mathrm{p}$ & $<0.000 l$ & $<0.001$ & $<0.05$ & NS & $<0.0001$ & $<0.0001$ & $<0.0$ & $<0.05$ \\
\hline
\end{tabular}

TABLE III Pharmacodynamic data

\begin{tabular}{|c|c|c|c|c|c|c|c|}
\hline & \multicolumn{3}{|l|}{ Polency } & \multicolumn{2}{|c|}{ Dwation of $0.01 \mathrm{mg}^{\mathrm{kg}} \mathrm{g}^{-1}$} & \multicolumn{2}{|l|}{$T 4|T\rangle$} \\
\hline & \multirow{2}{*}{$\begin{array}{l}k 050 \\
\left(\mu g \mathrm{~kg}^{-1}\right)\end{array}$} & \multirow{2}{*}{$\begin{array}{l}\text { EDs } 90 \\
\left(\mu g \cdot k g^{-1}\right)\end{array}$} & \multirow{2}{*}{$\begin{array}{l}E D 95 \\
\left(\mu g \cdot \mathrm{kg}^{-1}\right)\end{array}$} & \multirow{2}{*}{$\begin{array}{l}\text { Ist dows } \\
\text { (min) }\end{array}$} & \multirow{2}{*}{$\begin{array}{l}10 \text { h dose } \\
(\mathrm{min})\end{array}$} & \multicolumn{2}{|c|}{ minutes affer neostignine } \\
\hline & & & & & & 5 & 10 \\
\hline Normal & 31 & 49 & 57 & $7.7 \pm 0.8$ & $8.3 \pm 0.6$ & $0.44 \pm 0.05$ & $0.67 \pm 0.04$ \\
\hline Renal failure & 27.5 & 43 & 49 & $9.0 \pm 0.8$ & $13.8 \pm 2.0$ & $0.54 \pm 0.03$ & $0.69 \pm 0.03$ \\
\hline
\end{tabular}

of dispersion. Probabilities were calculated from Student's t test, and chi-square analysis and the null hypothesis rejected when $\mathrm{p}<0.05$.

\section{Results}

There were no significant differences in the sex ratios $\left(\chi^{2}\right)$, ages, weights or severity and duration of surgery between the two groups (Table [). However, there were significant differences in the laboratory data (Table II). In particular, haemoglobin concentration was lower and blood urea and serum creatinine concentrations were increased in the renal failure group.

The log-probit dose response curves for the two groups are shown in Figure 1. The curves were parallel and not significantly different from each other. Doses which produced 50, 90 and 95 per cent were obtained by interpolation and are recorded in Table III.

The durations of action of "top-up" doses of 0.01 $\mathrm{mg} \cdot \mathrm{kg}^{-1}$ are shown in Figure 2 and Table III, In those patients who received more than ten doses of vecuronium there was a progressive, significant increase in the duration of action in the renal failure group of approximately 50 per cent over two hours. This cumulation was not seen in the patients with normal renal function. Mean duration of action of "tnก-up" doses was greater in the renal failure group $(i 2.0 \pm 1.4)$ than in the control group $(7.3 \pm 0.7 ; p$ $<0.05$ ) (Figure 2).

After antagonism of the block with neostigmine, recovery occurred rapidly and at a similar rate in both groups (Table III). All patients were extubated at the end of surgery and no problems with ventilation were seen postoperatively.

\section{Discussion}

Until recently the choice of non-depolarizing neuromuscular blocking drugs to provide muscle relaxation for prolonged operations in patients with renal failure has been limited. Alterations in the pharma-

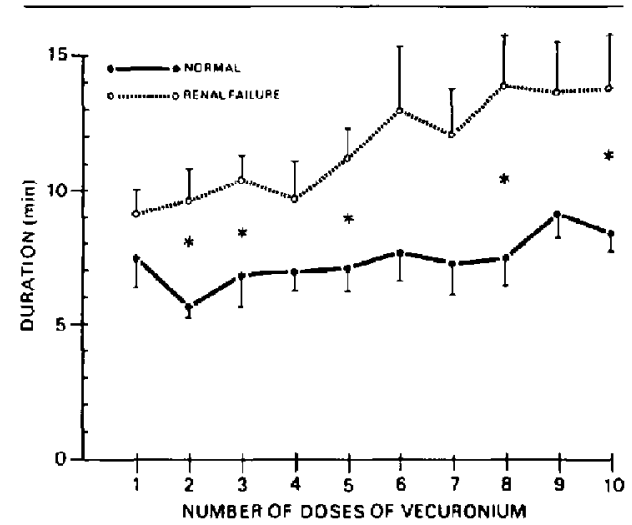

FIGURE 2 Durations of action of repeated small doses of vecuronium $\left(0.01 \mathrm{mg} \cdot \mathrm{kg}^{-1}\right)$ in patients receiving ten or more "top-ups." Significant differences between the mean values of the twa groups are shown. 
TABLE IV Phamacokinetics of non-depolarizing relaxants

\begin{tabular}{|c|c|c|c|c|}
\hline & & $\begin{array}{l}r: \beta \\
(\mathrm{min})\end{array}$ & $\begin{array}{l}V d_{s s} \\
\left(l \cdot \mathrm{kg}^{-i}\right) .\end{array}$ & $\begin{array}{l}\mathrm{Cl} \\
\left(\mathrm{ml} \cdot \mathrm{kg}^{-1} \cdot \mathrm{mi} \mathrm{r}^{-1}\right)\end{array}$ \\
\hline \multirow[t]{2}{*}{ Gallamine $^{10}$} & Normal & 131 & 0.21 & 1.2 \\
\hline & Rena! failure & 752 & 0.29 & 0.24 \\
\hline \multirow[t]{2}{*}{ Mctocurine $^{\text {I }}$} & Normal & 3.60 & 0.47 & 1.2 \\
\hline & Renal failure & 684 & 0.35 & 0.38 \\
\hline \multirow[t]{2}{*}{ Pancuronium ${ }^{12}$} & Normal & 133 & 0.26 & 1.8 \\
\hline & Renal failure & 257 & 0.3 & 0.9 \\
\hline \multirow[t]{2}{*}{ d-tubocurarine ${ }^{13}$} & Normal & 89 & 0.3 & 3.0 \\
\hline & Renal failure ${ }^{14}$ & $\uparrow$ & & $\downarrow$ \\
\hline \multirow[t]{2}{*}{ Atracurium ${ }^{15}$} & Normal & 10 & 0.12 & 7.6 \\
\hline & Renal failure & 23 & 0.17 & 6.7 \\
\hline \multirow[t]{2}{*}{ Vecuronium ${ }^{7}$} & Normal & 80 & 0.19 & 3.0 \\
\hline & Renal failure & 97 & 0.24 & 2.5 \\
\hline
\end{tabular}

$t_{2} \beta=$ half-time of the terminal elimination phase

$V_{d_{s s}}=$ volume of distribution at steady state.

$\mathrm{Cl}=$ plasma clearance.

cokinetic behaviour (Table IV) of the established agents results in increased durations of action. The clearances of gallamine and metocurine are decreased considerably because the kidney is their predominant route of excretion and, thus, their use is contraindicated in renal failure. Pancuronium and d-tubocurarine have an alternative hepatic route of excretion but plasma clearance is still reduced by approximately half. Recently, Hunter et al. ${ }^{16}$ confirmed that the duration of action of single doses of atracurium was not prolonged and there was no evidence of cumulation. Limited studies with vecuronium suggested that the minimal pharmacokinetic alterations induced by renal failure were associated with only minor pharmacodynamic changes.

The present study confirmed these findings. Although the duration of action of repeated doses of vecuronium were significantly longer with nonfunctioning kidneys, the increases were of minimal clinical importance. More interesting was the observation that cumulative effects were scen after repeated doses in patients with renal failure but not in normal controls. The reason for this difference is not understood. Theoretically, cumulation occurs as a result of progressive increases in either the drug half-life or the sensitivity of the neuromuscular junction to circulating relaxant. Alternatively, cumulation may be seen if repeated doses are injected during the distributional phase of the previous dose Whatever the aetiology the effect was to prolong the duration of action by about 50 per cent after ten doses, or two hours. This cumulation is less than that observed by Fahey ef $a l^{4}$ following repeated doses of pancuronium but they gave the drug for over six hours. Studies with the newer agents will need to be repeated for similar durations before it can be concluded that cumulative effects are absent.

The potency of vecuronium in normal patients in the present study was similar to that reported by Gramstad and Lilleaasen ${ }^{17}$ but less than that reported by others ${ }^{4,18}$ using either different methods of measurement or different anaesthetic combinations. No alteration in potency could be detected in patients with renal failure despite differences in electrolyte and plasma protein concentrations and possible fluid volume shifts from recent dialysis. In particular, the anephric patient for parathyroidectomy demonstrated normal sensitivity to vecuronium but her serum calcium concentration after haemodialysis was within the normal range.

Recovery of neuromuscular function after neostigmine proceeded as rapidly in the renal failure group as in normals. The rate of recovery was similar to or faster than that described previously for pancuronium ${ }^{19}$ in renal failure. In normal patients it has been demonstrated that recovery of neuromuscular function after neostigmine antagonism was quicker with vecuronium than pancuronium. ${ }^{20}$ There was no evidence of reparalysis in either group confirming that if a non-depolarizing neuro- 
muscular block is adequately antagonized fears of postoperative recurarization in renal failure are unfounded. ${ }^{21}$

In conclusion, vecuronium has suitable neuromuscular blocking effects to be used as a muscle relaxant in patients in renal failure. In these patients, the potency and reversibility of the drug are not affected by renal dysfunction. Nithough the duration of action of small repcated doses is slightly longer and demonstrates some cumulation, it is unlikely that these will be associated with difficulty in clinical management. When these properties are combined with the absence of cardiovascular activity, vecuronium represents a considerable advantage over existing agents in the provision of muscle relaxation to the patient in renal Cailure.

\section{References}

I Upion RA, Nguyen T-L, Miller RD, Castagnoli $N$ Renal and biliary elimination of vecuronium (ORG NC45) and pancuronium in rats. Anesth Analg 1982;61: 313-6.

2 Savege DS, Sleigh $T$, Carlyle $I$. The emergence of ORG NC45, 1-( (2 $\beta, 3 \alpha, 5 \alpha, 16 \beta, 17 \beta)-3,17$ bis(acetyloxy)-2-(1-piper-idinyl)-androstan-16-yl) ) 1-methylpiperidinium bromide from the pancuronium series. Br J Anaesth 1980; 52: 3S-9S.

3 Marshall $1 G$, Gibb AJ, Durant NN. Neuromuscular and vagal blocking actions of pancuronium bromide its metabolites, and vecuronium bromide (ORG NC45) and its potential metabolites in the anaesthetized cat. Br J Anaesth 1983; 55: 703-14.

4 Fahey MR, Morris RB, Miller RD, Sohn YJ Cronnelly R. Gencarell P $^{\prime}$. Clinical pharmacology of ORG NC45 (Norcuron): A ncw nondepolarizing muscle relaxant. Anesthesiology 1981; 55: 6-11.

5 Durant NN, Houwerties MC, Agoston S. Renal elimination of ORG-NC45 and pancuronium. Anesthesiology $1979 ; 51: S 266$

6 Meisleiman C, Lienhart A, Leveque C. Bitker MO Pigot $B$. Pharmacology of vecuronium in paticnts with end stage renal failure. Anesthesiology 1983; 59 : A293.

7 Fahey MR, Morris RB. Miller RU. Nguyen T-L, Upron RA. Pharmacokinetics of ORG NC45 (Norcuron) in patients with and without renal failure. Br J Anaesth 1981; 53: 1049-53.

8 Ali $H H$, Utting JE, Gray $C$. Stimulus frequency in the detection of neuromuscular block in humans. $\mathrm{Br} J$ Anaesth 1970; 42: 967-78.
9 Litchfield JT, Wilcoxon F. A simplified method of evaluating dose-effect experiments. J Pharmacol Exp Ther 1949; 96: 99-113.

10 Ramzan $M I$, Shanks CA, Triggs EJ. Gallamine disposition in surgical patients with chronic renal failure. Br J Pharmacol 1981: 12: 141-7.

II Brotherton WP, Matteo RS. Pharmacokinetics and pharmucodynamies of metocurine in humans with and without renal failure. Anesthesiology 1981; 55 : 273-6.

12 Somogyi A, Shanks CA, Triggs EJ. The effect of renal tailure on the disposition and neuromuscular blocking action of pancuroniun bromide. Earope J Clin Pharmacol 1977; 12: 23-9.

13 Fisher DM, O'Kecffe C, Stanski $D R$, Cronnelly $R$. Miller RD. Gregory GA. Pharmacokinetics and pharmacodynamics of d-tubocurarine in infants, children and adults. Anesthesiology 1982;57:203-8.

14 Miller RD, Matteo RS, Benet LZ, Sohn $Y J$. The pharmacokinetics of d-tubocurarine in man with and without renal failure. J Pharmacol Exp Ther 1977; 202: 1-6.

15 Fahey MR, Rupp SM, Fisher DM, et al. Pharmacokinetics and pharmacodynamics of atracurium in normal and renal failure patients. Anesthesiology 1983; 59: A263.

16 Hunter JM, Jones RS, Utring JE. Use of atracurium in patients with no renal function. Br J Anaesth 1982; 54: $1251-8$.

17 Gramstad L, Lilleacasen $P$. Dose-response relation for atracurium, ORG NC45 and pancuronium. Br J Anaesth 1982; 54: 647-51.

18 Krieg N, Crul JF, Booij LHDJ. Relative potency of ORG NC45, pancuronium, alcuronium and tubocurarine in anaesthetized man. Br J Anaesth 1980; 52 : $783-8$.

19 Bevan DR, Archer D, Donati F, Ferguson A, Higgs $B D$. Antagonism of pancuronium in renal failure: no recurarization. Br J Anacsth 1982; 54:63-8.

20 Williams A, Gyasi $H$, Melloni $C$, Bevan DR. Clinical experience with ORG $\mathrm{NC45}$ (Norcuron) as the sole muscle relaxant. Can Anaesth Soc J; 29: 567-72

21 Miller RD, Cullen $D J$. Renal failure and postoperative respiratory failure: rccurarization? $\mathrm{Br} \mathbf{J}$ Anaesth 1976; 48: 253-6. 


\section{Résumé}

Le bloc nesromusculaire a élé cffectué avec du vécuronium chez 24 patients en defaillance rénale terminale et chez 21 patients normaux qui ont constitué le groupe contôle. Les courbes de réponse quion a érablies ont montré que les doses nécessaires pour produire un bloc neuronusculaire de 50, 90 et 95 pour cent étaient respectivement de 27.5, $43 \mathrm{et} 49 \mathrm{\mu g} \cdot \mathrm{kg}^{-1}$. Ces doses ne diffèrent pas sensiblement des doses nécessaires chez les patients normaux qui sont respectivement de 31,49 e 157 $\mu \mathrm{g} \cdot \mathrm{kg}^{-1}$.

Des petites doses répétées de $0.01 \mathrm{mg} \cdot \mathrm{kg}^{-1}$ provoquaient un bioc neuromuscalaire de plus longue darée possiblement relié à un cerrain degré d'accumulation dans ie groupe en défailiance rénale. La disparition du bloc s'est effectuée rapidement à la suite de néostigmine dans l'un et lautre groupes et on n'a pas observé de récurarisation chez les insteffisants rénaux. On conclut que le vécuronium, administré d̀ des patients en défaillance rénale possède certains avantages sur les autres - agents connus, en particulier une durée d'action plus courte et une réponse assurée à la néostigmine. 